\title{
The Existence Of Regional Representative Boards In The Indonesian Representative Institution System
}

\author{
Alexander J Sinukaban \\ North Sumatera University Faculty Of Law. E-mail: alexander@gmail.com
}

\section{ARTICLE INFO}

Keywords:

Existence, Regional

Representative System,

Article history:

Received Sept 21, 2019;

Revised Oct 15, 2019;

Accepted Des 28, 2019;

Online Jan 30, 2020.

\begin{abstract}
The Regional Representative Council is a state institution that has a certain structure, position, task and authority by the 1945 Constitution which has been amended. With the presence of this state institution, it also influences and changes the structure of the people's representative institutions in Indonesia, and also the Indonesian state administration system. In the course of the system of Indonesian representative institutions, there was an institution whose duties and capacities were similar to those of the Regional Representatives Council, namely the Senate. Where the Senate was formed during the validity period of the RIS Constitution, along with the development of the Indonesian state administration, this institution was also erased when the Indonesian Constitution returned to the 1945 Constitution. The existence of this institution was replaced with Regional Representatives and Group Delegates, in which they represented regions and groups. certain groups in Indonesia. The first, second, third, and fourth amendments to the 1945 Constitution gave birth to the Regional Representative Council where with this amendment there was a change in the Indonesian state administration system, where with this amendment the People's Consultative Assembly changed both its structure and position, in its structure the People's Consultative Assembly The People's Representative Council consists of the People's Representative Council and the Regional Representative Council, while its position is no longer the highest state institution, but it is equal to the DPR, DPD, President, and other State Institutions as State High Institutions. The Regional Representative Council has similarities with several similar institutions in other countries, namely the Senate (United States) and the State Council (Malaysia) where they already have a strong position in the parliamentary system in their respective countries. The position, duties, rights, and authorities of the Regional Representatives Council in the Indonesian state administration system do not appear to have the same power as the very powerful House of Representatives. This is what invites debate in the existence of the Regional Representative Council. Where the existence of the Regional Representative Council should be improved and given a position and authority that is equal to the Regional Representative Council.
\end{abstract}

This is an open access article under the CC BY-NC license.

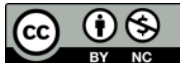

\section{Introduction}

Talking about the system of representative institutions means talking about the existing equipment to support the existence of a country. In his writings on the Theory of Political 
Representatives, Alfred de Grazia argues that representation is defined as a relationship between two parties, namely the representative and the representative where the representative holds the authority to take various actions related to the agreement he made with the represented.

This representative has a forum called a representative institution, where this representative institution is a forum for the formation of a systematic representation system. Currently the representative body or legislative body is called the parliament. A country that declares democracy must have this institution in its constitutional structure because apart from functioning as a channel for the aspirations of the people, parliament also functions as a supervisory function for other institutions, especially the executive.

In the 1945 Constitution before it was amended, there was a People's Consultative Assembly (MPR) and a People's Representative Council (DPR). Both are often considered as legislative institutions based on the 1945 Constitution. The DPR and MPR institutions based on the 1945 Constitution are indeed recognized as Indonesian parliaments.

According to Harun Alrasid, in his book entitled The Manuscript of the 1945 Constitution Has Been Amended Four Times, said that the state bodies formed by the makers of the 1945 Constitution were the transformation of the state apparatus during the Dutch East Indies era. Thus we see that the positions of Gouverneur General and Luitenant Gouvernuer Generaal were changed to President and Vice President, Directeur van een Departement to minister, Raad van Nederlands-Indie to the Supreme Advisory Council, Volksraad to DPR, Algemene Rekenkamer to the Supreme Audit Agency, and Hooggerechshof to the Supreme Court. . Meanwhile, to replace the position of the king/queen of the Netherlands, as the party for whom the Governor-General must be responsible, the People's Consultative Assembly (MPR) was created, which holds the sovereignty of the people, and to which the president must give accountability.

Meanwhile, the DPR, according to the background of thought of the makers of the Constitution, is a forum for representatives of political parties (Parpol) as a result of the election. However, not everyone joins a political party so that the DPR does not represent "all" the people. Then a larger body was established, namely the MPR. Which consists of all members of the DPR plus representatives of the people of non-political parties, namely regional and group representatives.

The election regarding the organizational structure of the parliament in Indonesia, namely whether the system is unicameral or bicameral, has become hot again after the amendment to the 1945 Constitution. In the sessions of the MPR, all kinds of constitutional changes have been made. These changes were embodied in four amendments to the 1945 Constitution and various MPR Decrees that gave birth to fundamental changes in Indonesia's constitutional structure.

Change is a natural thing, both in normal political and constitutional situations as well as in the midst of a transition from authoritarian rule. To implement the amendments to the 1945 Constitution, the MPR formed the MPR Working Body to carry out the task of preparing the draft amendments to the 1945 Constitution. Hoc.

In the midst of the process of amending the 1945 Constitution, the Ad Hoc I committee drew up a basic agreement relating to the amendment of the 1945 Constitution, the basic agreement consisted of 5 (five) points, namely:

a. Does not change the preamble to the 1945 Constitution

b. Keep defending the Unitary State of the Republic of Indonesia

c. Strengthen the presidential system of government

d. The explanation of the 1945 Constitution which contains normative matters will be 


\section{included in the articles \\ e. Make changes by way of addendum}

In terms of the number of members, as stated in Article 22C paragraph (2) the third amendment to the 1945 Constitution affirms that the number of DPD members does not exceed one third of the members of the DPR. With this kind of composition, it seems difficult not to state that the existence of the DPD is more of a supplementary element than actually accommodating the interests of the community at the local level.

The DPD which emerged as a product of the third amendment to the 1945 Constitution (Articles $22 \mathrm{C}$ and 22D) is a provincial political representative institution which is elected through a direct election. The proportion for DPD membership in each province is the same, i.e. four people per province are non-partisan. The total number of DPD members is 128 members. The dilemma of the DPD as a nationally elected regional people's representative institution is that its political prestige is increasingly unpopular and its legitimacy base is unclear. Unlike the people's representatives who represent the votes of political parties, the political basis of the DPD is completely unclear.

The DPD does not have a clear political mass base and is not supported by the emotional and ideological relationship with its voters as political parties do. That is, the presence of the DPD as part of delegative democracy, does not represent the fragmentation of the participation of party political ideologies at the real level of the political masses, but rather leads as a seat of regional political representative institutions.

In the constitutional realm, the position of the DPD is not commensurate with the amount of political authority held by the DPR. This further strengthens the position of the DPD as a quasi-political representative institution that only acts as a consultative council in every legislative process. Because of this, the DPD has lost in prestige compared to the DPR, which has broader, clearer and more powerful powers. Although both were elected through a democratic mechanism, namely the 2004 election, the presence of the DPD in the national political stage seemed only as a seasoning, considering that the center of attraction in the postNew Order national political map was heavier between the DPR and the government (president).

The authority of the DPR as stated in the constitution is equal to that of the executive. Even the powerful position of the DPR can be seen from the authority it has to form, stipulate and ratify laws with the government.

\section{Method}

The method used by the author to obtain data and information needed in compiling this thesis is through library research, namely how to obtain data from several reading sources to be used as a reference in compiling the thesis. Where the data sources that the author uses are books and laws and regulations. The data obtained from library research is primary data. And the writing method that the author uses in writing this thesis is a comparative descriptive writing method, namely how to write scripts by describing a reference material and comparing.

\section{Analysis and Results}

Judging from the political history of modern Indonesia, state institutions that specifically represent regional interests are not a new idea because Indonesia once had a Senate during the United States of Indonesia (RIS) in 1949-1950. The Senate was formed because Indonesia used the form of a federal state. After the Unitary State of the Republic of Indonesia (NKRI) was formed again on August 17, 1950, the Senate was automatically abolished. However, it should be noted that the Senate practically did not have sufficient opportunity to work because of the 
emergence of various political conflicts that demanded the abolition of the RIS and the reestablishment of the Unitary State of the Republic of Indonesia.

The demand for the formation of the DPD is one of the efforts to produce a more democratic government considering the diverse interests and conditions of the regions in Indonesia. Indonesia is one of the countries in the world that has a high level of heterogeneity (progress). Although it is not a requirement for the establishment of democracy, the DPD is considered an institution that can represent a very important meaning because the central government in the Unitary State of the Republic of Indonesia plays a very important role in Indonesian politics.

DPD is a representative body at the central level (Third Amendment to the 1945 Constitution). According to Bagir Manan, there are various ideas behind the birth of the DPD, namely:

a. The idea of turning the representative system into a two-chamber (bicameral) system. The DPD and the DPR are described as similar to the representative system in the United States, which consists of the Senate as state representatives, and the House of Representatives as representatives of all the people. In the United States, the two elements of representation are called Congress (Congress). Article 1 paragraph (1) of the United States Constitution (1787) states: All legislative powers granted shall be vested in a Congress of the United States, which shall consist of a Senate and House of Representatives.

b. The idea of increasing regional participation in the course of politics and state management. The DPD is a day-to-day body that participates in determining and overseeing the course of politics and state management. Thus, the DPD can also be seen as a correction or refinement of the Regional Representatives system in the MPR according to the provisions of Article 2 paragraph (1) of the 1945 Constitution before the amendment. Regional participation in Regional Representatives in the MPR is very limited, namely during MPR sessions (during the New Order, only twice in five years).

c. With the presence of the DPD, in the Indonesian representative system, the DPR is supported and strengthened by the DPD, the DPR is a representative institution based on the aspirations and political understanding of the people as the holder of sovereignty, while the DPD is an institution that distributes the diversity of regional/regional aspirations. The existence of the DPD institution accommodates the principle of regional/regional representation. The representative system adopted by Indonesia is a uniquely Indonesian system, because it was formed as an embodiment of the needs, interests, and challenges of the Indonesian nation and state.

The provisions of the 1945 Constitution which regulates the existence of the DPD in the Indonesian constitutional structure are intended, among other things, to:

a. Strengthening regional ties within the unitary State of the Republic of Indonesia and strengthening national unity of all regions.

b. Increase the aggregation and accommodation of aspirations and interests of the regions in the formulation of national policies relating to the state and regions.

c. Encouraging the acceleration of democracy, development and regional progress in a harmonious and balanced manner.

The political implications that will arise from the reason for the existence of the DPD which is intended to strengthen the integration of the nation can create new problems, if it turns out that the struggle of the members of the DPD to advance their respective regions is not successful. If the very limited functions and roles of the DPD are not reviewed, then the process of strengthening the nation's integration is only an empty political hope. This problem will become even more complex if the central government does not stick to its commitment to develop and advance all regions more equitably and equitably.

The reason for the existence of the DPD which is intended to increase the aggregation and accommodation of aspirations in the context of formulating national policies for the interests of 
the state and regions is indeed a very rational argument. However, if the functions and authorities of the DPD are far below the DPR, then the function of aggregation and accommodation of political aspirations will not work properly. The DPD will also not be able to fully supervise national development policies.

The reason for the existence of the DPD, which is intended to increase the dynamics of democracy and accelerate development and regional progress, is of course an effort to increase the empowerment of blood and communities throughout Indonesia. This effort will also not likely be successful, if the DPD with its weaknesses is not able to carry out its duties proportionally as a high state institution. In this context, too, it is very difficult to expect the DPD to be able to get around its functions and authorities which are formulated in the Law on the Structure of the MPR, DPR, DPD and DPRD. As long as the DPD is not given proportional constitutional authority according to the Constitution, the task it carries will not succeed in accelerating the growth of democracy, development and regional progress in a fair and dignified manner.

\subsection{DPD Membership}

DPD members are elected from each province through general elections. 136 DPD members from each province are the same in number and the total number of DPD members is not more than one third of the total DPR members.

In Law No. 12 of 2003 and Law No. 10 of 2008 concerning General Elections, it is stated that the participants in the General Election to elect members of the DPD are individuals. The general election to elect members of the DPD is carried out with a multi-representative district system.

In order to become a candidate for DPD member, individual election participants must meet the requirements for support with the following conditions:

a. Provinces with a population of up to one million people must be supported by at least one thousand voters;

b. Provinces with a population of more than one million to five million people must be supported by at least two thousand voters;

c. Provinces with a population of more than five million to ten million people must be supported by at least three thousand voters;

d. Provinces with a population of more than ten million to fifteen million people must be supported by at least four thousand voters;

e. Provinces with a population of more than fifteen million people must be supported by at least five thousand voters.139

One of the main tasks of the MKDKI as stated in Article 64 of the Medical Practice Law is to "receive complaints, examine, and decide cases of violations of physician discipline". Based on the article, it can be said that the MKDKI is the authorized institution to determine whether or not there are errors made by doctors in the application of medical disciplines; and establish sanctions for dentists who are found guilty. Discipline violations are violations of the rules and/or provisions of the application of science, which can essentially be grouped into 3 things, namely:

a. Implementing medical practice incompetently

b. Professional duties and responsibilities to patients are not carried out properly

c. Disgraceful behavior that damages the dignity and honor of the medical profession

The support referred to is spread over at least twenty five percent of the total regencies/municipalities in the province concerned and in the latest Law it is regulated that fifty percent of the total number of. 


\subsection{DPD Member Rights}

In article 49 of Law no. 22 of 2003 concerning the Composition and Position of the MPR, DPR, DPD, and DPRD, which include:
a. Submit suggestions and opinions
b. Pick and choose
c. Self-defense
d. Immunity
e. Protocol, and
f. Finance and administrative

\subsection{Duties of DPD Members}

Article 50 of Law no. 22 of 2003 concerning the Composition and Position of the MPR, DPR, DPD, and DPRD stipulates the obligations of DPD Members, namely:
a. Practicing Pancasila
b. Implement the 1945 Constitution and comply with all laws and regulations.
c. Fostering democracy in governance
d. Maintaining and maintaining harmony and following up on community and regional aspirations
e. Paying attention to efforts to improve people's welfare.
f. Absorb, collect, accommodate and follow upaspirations community and area
g. Prioritizing the interests of the state above personal, group and group interests.
h. Providing moral and political accountability to voters and their constituencies
i. Obeying the DPD Code of Ethics and Code of Conduct; and
j. Maintain the DPD Code of Ethics and Code of Conduct; and
k. Maintain the ethics and norms of the region it represents

\subsection{Dismissal/Replacement Between DPD Members}

Regarding the interim replacement of DPD members, the 2003 Susduk Law is regulated in Article 88, Article 89 and Article 90. The explanation of this is as detailed below. Article 88, Law no. 22 of 2003 concerning the Composition and Position of the MPR, DPR, DPD, and DPRD members of the DPD terminate from time to time because:
a. Die
b. Resign as a member at his/her own request in writing.

DPD members are dismissed because:

a. Unable to carry out tasks on an ongoing basis or is unable to remain as a DPD Member

b. No longer meets the requirements as a member of the DPD as referred to in the Law on general elections

c. Is declared to have violated the oath/promise, the DPD code of ethics, and/or did not carry out his obligations as a member of the DPD.

d. Violating the provisions on the prohibition of concurrent positions as regulated in the provisions of the legislation.

e. Found guilty based on a court decision that has permanent legal force for violating a criminal act with a maximum penalty of five years in prison.

Dismissal of a member of the DPD who has fulfilled the provisions as intended (died, resigns as a member at his own request in writing, violates the provisions for concurrent positions as regulated in the provisions of the law, is declared guilty based on a court decision that has permanent legal force with a criminal threat as low as -at least five years in prison) was directly conveyed by the DPD leadership to the President for inauguration. 


\section{Conclusion}

History The People's Representative Council in Indonesia was formed at the beginning of Indonesia's independence, which was called the People's Consultative Assembly proposed by Bung Karno, M. Yamin, and Soepomo. Along with the journey of independence, in 1949 the Republic of Indonesia changed to the Republic of the United States of Indonesia (RIS), which in this change also occurred a change in the form of the state, so that at this time the People's Consultative Assembly was divided into two chambers. Namely the House of Representatives (DPR) and the Senate. Where in this case the DPR is the people's representative and the Senate is the regional representative. After returning to the form of the Republic of Indonesia (RI) in 1950, the existence of this senate was abolished and membership in the MPR was filled with members of the DPR who were elected from the election results and regional representatives along with group representatives who were substitutes for the Senate. In the third amendment to the 1945 Constitution in 2001, a new institution was formed within the system of Indonesian state institutions, namely the Regional Representatives Council (DPD), where this DPD resembles the Senate that existed during the period of the United States of Indonesia (RIS). Where the existence of this Regional Representative Council replaces the position of the Group Delegates and Regional Representatives where this DPD existence resembles the Senate that existed during the United States of Indonesia (RIS) era. Where the existence of this Regional Representative Council replaces the position of the Group Delegates and Regional Representatives where this DPD existence resembles the Senate that existed during the United States of Indonesia (RIS) era. Where the existence of this Regional Representative Council replaces the position of the Group Delegates and Regional Representatives

The second chamber or upper house is needed for a reason, namely to make a political contribution to a democratic political system, and bicameralism is important for theory and practice in democratic governance. The importance of establishing this second chamber includes its potential as a tool of consideration in influencing the legislative process, and as a symbol for enhancing democratic legitimacy by examining the majority movement of government. Usually the second chamber or the upper house tends to have an important influence in sharpening the output of policies issued by the legislature.

The existence of the Regional Representatives Council in the Indonesian parliamentary system can be seen after the 2001-2002 MPR Annual Session, namely: (a) According to the 1945 Constitution Fourth Amendment Article 2 paragraph (1), the Consultative Assembly consists of members of the DPR and members of the DPD who are elected through general elections and further regulated by law. (b) DPD is a territorial representative/provincial representative. Members of the DPD are elected by each province through general elections (Article 22C paragraph (1) of the Third Amendment of the 1945 Constitution), every five years (Article 22E, paragraph (1) Third Amendment of the 1945 Constitution). The participants are individuals (Article 22C paragraph (2) of the Third Amendment of the 1945 Constitution). (c) DPD in the legislative process only has the right to propose. Even that only relates to the region (Article 22D paragraph (1) of the Third Amendment of the 1945 Constitution). DPD can participate in discussing and supervising laws regarding regional autonomy, the formation and expansion and merger of regions, central and regional relations, management of natural resources and other economic resources, implementation of the budget and state expenditure revenues, education taxes, and religion (Article 22D). paragraph (d) Third Amendment of the 1945 Constitution). Legislative rights are very dependent on the DPR, which will approve or not the proposals, discussions and supervision carried out by the DPD.

The authority of the DPD other than in terms of legislation is (1) give consideration in selecting members of the BPK (Article 23F of the Third Amendment of the 1945 Constitution), (2) to supervise the implementation of the law on regional autonomy, the formation, expansion and merger of regions, central and regional relations, management of natural resources and other 
economic resources, implementation of APBN, taxes, education and religion. (3) DPD members as members of the MPR, have the authority to run as members of the MPR.

The DPD currently has a less important role so that it cannot carry out the checks and balances function perfectly, there is no veto right on bills and only has the right to propose certain bills, and the function of consideration and supervision is very dependent on and relying on other parties, especially DPR and the Government (President) to follow up without having any sanctions. The authority given by the constitution to the DPD institution may not benefit the region if the DPR and the government are not aspirational towards regional interests because the establishment of the DPD is intended so that regional aspirations and interests can be optimally channeled to the center. Thus the disintegration of the nation can be prevented.

\section{References}

Alrasid, Aaron. The Manuscript of the 1945 Constitution After Four Amendments by the MPR, Jakarta: UI Press, 2003.

Asshidiqie, Jimly. The Struggle of the Role of Government and Parliament in History, Jakarta: UI Press, 1996.

Boboy, Max, DPR RI in the Perspective of History and State Administration, Jakarta: Sinar Harapan Library, 1994.

Manan, Bagir. DPR, DPD and MPR in the New 1945 Constitution, Jakarta: UI Press, 2004.

Marbun, BM DPR-RI Growth and How it Works. Revised edition. Jakarta: Dep. P and K, 2000.

Napitupulu, Paimin. Towards Representative Government, Bandung: Alumni, 2007.

Pieris, John and Aryanthi Baramuli Putri. DPD RI Study, Analysis, Criticism and Solutions for Legal and Political Studies, Jakarta: Pelangi Cendekia, 2006.

Full moon, Eddy. Analysis of the Indonesian Government System and its Comparison with Other Countries, Bandung: Nusamedia, 2007.

Purnomowati, Reni Dwi. Implementation of the Bicameral System in the Indonesian Parliament, Jakarta: PT Raja Grafindo Persada, 2005.

Sanit, Arbi. Political Representative in Indonesia, Jakarta: CV Rajawali, 1985.

Thaib, Dahlan. Implementation of the State Administration System According to the 1945 Constitution, Yogyakarta: Liberty, 1993.

. Legal and Constitutional Theory, Jakarta: PT Raja Grafindo Persada, 1999.

Wahidin, Syamsul. MPR from Time to Time, Jakarta: Bina Aksara, 1986.

Kris Nugroho, DPD Problems: Between Constitutional Functions and Political Reality www.journal.unair.ac.id/filerPDF/Problematika\%20Dewan\%20Representative\%20Region.pdf accessed on 10 November 2008.

http : /www.parlimen.gov.my/Dew.Negara_infoumum.php\#upabit.08 September 2008.

"DPD" and President You're welcome Get Mandate direct", www.kompas.com accessed on 02 December 2008. 
1945 Constitution of the Republic of Indonesia Constitution of the RIS (United States of Indonesia).

The 1945 Constitution of the Republic of Indonesia Amendments I.II, III and IV.

Law No. 22 of 1999 concerning Regional Government Law No. 12 of 2003 concerning General Election of Members DPR, DPD and DPRD. 